\title{
Determination of garnet oxidation state using Mössbauer, XANES and the flank method
}

\author{
A.J. Berry ${ }^{1}$, A.B. Woodland ${ }^{2}$, G.M. Yaxley ${ }^{3}$, and H.E. Höfer ${ }^{2}$ \\ ${ }^{I}$ Department of Earth Science and Engineering, Imperial College London, South Kensignton, London SW7 2AZ, UK \\ ${ }^{2}$ Institut für Geowissenschaften, Johann Wolfgang Goethe Universität, Altenhöferallee 1, Frankfurt am Main, D- \\ 60438, Germany \\ ${ }^{3}$ Research School of Earth Sciences, Australian National University, Canberra, ACT 0200, Australia
}

\section{Introduction}

Fe is the most common element in the Earth that exhibits a variable oxidation state occurring as both $\mathrm{Fe}^{2+}$ and $\mathrm{Fe}^{3+}$ in minerals and melts. The $\mathrm{Fe}^{3+} / \mathrm{Fe}_{\text {tot }}$ ratio of geological samples can be used as an indicator of the redox conditions or oxygen fugacity $\left(f \mathrm{O}_{2}\right)$ at which a mineral formed.

Garnets are a mineral group which may contain both $\mathrm{Fe}^{2+}$ and $\mathrm{Fe}^{3+}$. At depths below $\sim 60 \mathrm{~km}$ where garnet bearing peridotites are stable, the $\mathrm{Fe}^{3+}$ component in garnet can be used to determine the $\mathrm{fO}_{2}$ of the mantle (Gudmundsson and Wood 1995). In conjunction with data from geothermometers (e.g. two pyroxene or olivine-garnet) and geobarometers (e.g. Al in orthopyroxene) this allows the $\mathrm{fO}_{2}$ of the mantle to be profiled as a function of depth (Woodland and Koch 2003). The $f \mathrm{O}_{2}$ of the mantle is particularly important as an indicator of diamond (as opposed to carbonate) stability. For depths corresponding to pressures greater than the graphite to diamond transition the mantle $f \mathrm{O}_{2}$ is, as expected, sufficiently reduced for diamond to be stable. However, post formation metasomatic processes may impose significantly higher $\mathrm{fO}_{2}$ conditions leading to diamond breakdown or resorption. Such events will usually be recorded by the coexisting garnet as oxidised rims, which also exhibit differences in both major and trace element composition (McCammon et al. 2001). To enhance the use of garnet as a diamond indicator mineral in exploration and to predict the potential diamond grade of kimberlites, it is necessary to determine $\mathrm{Fe}^{3+} / \mathrm{Fe}_{\text {tot }}$ with micron spatial resolution.

Due to the importance of $\mathrm{Fe}^{3+} / \mathrm{Fe}_{\text {tot }}$ as a variable in geological systems significant effort has been devoted to refining methods for its determination. Chemical titrations are common although these involve dissolution and hence destruction of the sample and also lack spatial resolution. Mössbauer spectroscopy is arguably the most accurate method currently available, with a milliprobe technique allowing spectra to be collected from areas as small as $\sim 100 \mu \mathrm{m}$. In a recent study a $400 \mu \mathrm{m}$ aperture was used to determine $\mathrm{Fe}^{3+} / \mathrm{Fe}_{\text {tot }}$ of metasomatised garnets, identifying the $f \mathrm{O}_{2}$ of the rims as being two log units more oxidised than the core (McCammon et al. 2001). However, the spectra take days to acquire, which coupled with the poor spatial resolution, severely limit the ability to analyse large numbers of samples or to distinguish between rims and cores. An alternative technique involves use of the electron microprobe to determine $\mathrm{Fe}^{3+} / \mathrm{Fe}_{\text {tot }}$ from the ratio of the $L \beta / L \alpha$ lines in the fluorescence spectrum (Höfer and Brey 2007). This "flank method" has the potential to provide routine determinations of $\mathrm{Fe}^{3+} / \mathrm{Fe}_{\text {tot }}$ for garnets although careful calibration is required.

A further technique is X-ray Absorption Near Edge Structure (XANES) spectroscopy, undertaken at a synchrotron light source, which is capable of determining $\mathrm{Fe}^{3+} / \mathrm{Fe}_{\text {tot }}$ to \pm 0.02 with sub-micron spatial resolution (Delaney et al. 1998). The method relies on systematic changes in the energy of spectral 
features with $\mathrm{Fe}^{3+} / \mathrm{Fe}_{\text {tot }}$ (Berry et al. 2003). Here we report XANES results for both synthetic and natural garnets.

\section{Experimental}

Synthetic garnets of the of the almandine"skiagite" $\left(\mathrm{Fe}_{3}{ }^{2+} \mathrm{Al}_{2} \mathrm{Si}_{3} \mathrm{O}_{12}-\mathrm{Fe}_{3}{ }^{2+} \mathrm{Fe}_{2}{ }^{3+} \mathrm{Si}_{3} \mathrm{O}_{12}\right)$ and andradite-"skiagite" $\left(\mathrm{Ca}_{3} \mathrm{Fe}_{2}{ }^{3+} \mathrm{Si}_{3} \mathrm{O}_{12}-\right.$ $\left.\mathrm{Fe}_{3}{ }^{2+} \mathrm{Fe}_{2}{ }^{3+} \mathrm{Si}_{3} \mathrm{O}_{12}\right)$ solid sultion series have been prepared previously (Woodland and O'Neill 1993, 1995; Woodland and Ross 1994). $\quad \mathrm{Fe}^{3+} / \mathrm{Fe}_{\text {tot }}$ was determined by stoichiometry and Mössbauer spectroscopy. The samples form a suite of standards in which $\mathrm{Fe}^{3+} / \mathrm{Fe}_{\text {tot }}$ varies from 0 to 1.0 . $\mathrm{Fe}^{3+} / \mathrm{Fe}_{\text {tot }}$ was also determined by Mössbauer spectroscopy for a number of natural garnets, which can be considered as secondary standards.

Fe $K$-edge XANES spectra were recorded in fluorescence mode, using a $\mathrm{Si}$ (111) channel cut crystal monochromator, at the Australian National Beamline Facility; Beamline 20B (bending magnet) at the $2.5 \mathrm{GeV}$ Photon Factory (KEK, Tsukuba, Japan). Powdered garnet samples mounted on plastic film, prepared for transmission X-ray diffraction experiments, were oriented at $45^{\circ}$ to both the excitation beam and detector. An Fe foil reference absorption spectrum was simultaneously acquired using the transmitted beam, allowing the energy of every sample to be individually calibrated by defining the first derivative peak of the $\mathrm{Fe}$ foil spectrum to be $7112.0 \mathrm{eV}$.

\section{Results and Discussion}

Fe K-edge XANES spectra of synthetic almandine and andradite are shown in Figure 1. The spectra exhibit an absorption edge and a pre-edge feature corresponding to the $1 \mathrm{~s}$ $\rightarrow 3 \mathrm{~d}$ transition. The energy of both the edge and pre-edge increases with increasing $\mathrm{Fe}^{3+} / \mathrm{Fe}_{\text {tot }}$ (Berry et al. 2003). The pre-edge feature is shown in detail for andradite in Figure 2. It comprises transitions to the crystal field levels of $\mathrm{Fe}^{2+}$ and $\mathrm{Fe}^{3+}$ in the dodecahedral and octahedral garnet sites respectively. From crystal field theory two transitions are expected for $\mathrm{Fe}^{3+}$ in an octahedral site. The pre-edge spectrum was

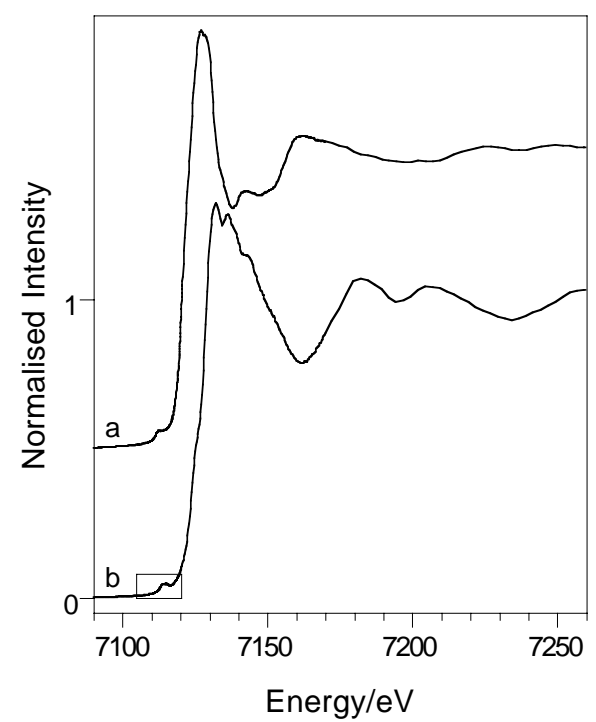

Fig. $1 \mathrm{Fe} \mathrm{K}$-edge XANES spectra of (a) almandine $\left(\mathrm{Fe}_{3}{ }^{2+} \mathrm{Al}_{2} \mathrm{Si}_{3} \mathrm{O}_{12}\right)$ and (b) andradite $\left(\mathrm{Ca}_{3} \mathrm{Fe}_{2}{ }^{3+} \mathrm{Si}_{3} \mathrm{O}_{12}\right)$. The pre-edge region of andradite, indicated by the box, is shown in more detail in Figure 2.

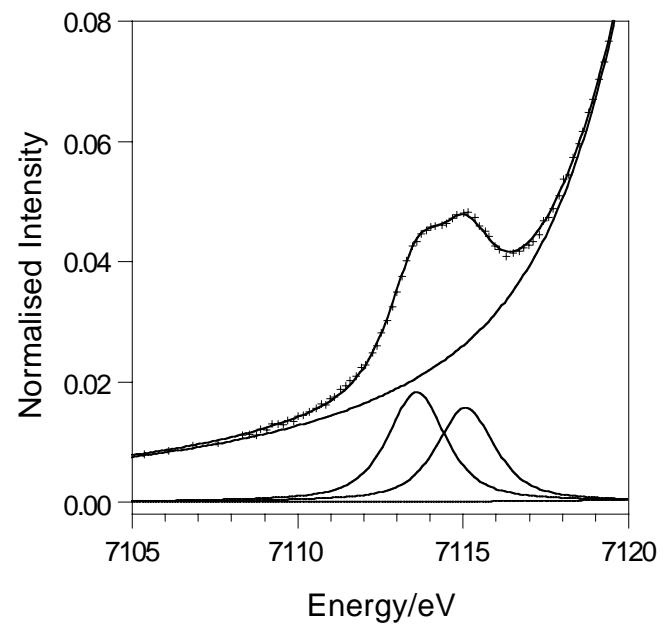

Fig. 2 Pre-edge region of andradite showing the raw data (symbols), the resultant fit, baseline, and pseudo-Voigt components.

thus fit to two peaks, with both the width and lineshape constrained to be equal. The resulting width of $2.1 \mathrm{eV}$ and lineshape of 23\% Lorentzian and 77\% Gaussian (pseudoVoigt) are in excellent agreement with that expected from the resolution of the beamline and the intrinsic width of the electronic transition (2.2 $\mathrm{eV}$ and 33\% Lorentzian). The background under the pre-edge was fit simultaneously to the tail of a pseudo-Voigt function. 
For garnets containing both $\mathrm{Fe}^{2+}$ and $\mathrm{Fe}^{3+}$ it is difficult to theoretically model the multiple contributing components. Indeed, this is unnecessary and the intensity weighted energy, or centroid, of the background subtracted pre-edge can be used for calibrating and quantifying $\mathrm{Fe}^{3+} / \mathrm{Fe}_{\text {tot }}$ (Berry et al. 2003).

The centroid energy of the garnet standards as a function of $\mathrm{Fe}^{3+} / \mathrm{Fe}_{\text {tot }}$ is shown in Figure 3. The centroids for both the almandine-skiagite and andradite-skiagite series are linearly correlated with $\mathrm{Fe}^{3+} / \mathrm{Fe}_{\text {tot }}$. The slopes of the calibration curves for each series are constant although there is a discontinuity or offset near $\mathrm{Fe}^{3+} / \mathrm{Fe}_{\text {tot }}=0.3$. This strongly suggests a compositional effect on the centoid energy for a given value of $\mathrm{Fe}^{3+} / \mathrm{Fe}_{\text {tot. }}$. The natural garnets have similar $\mathrm{Fe}^{3+} / \mathrm{Fe}_{\text {tot }}$ values of $\sim 0.1$ but exhibit a range of centroids between the two calibration curves. This range may also reflect the effect of composition.

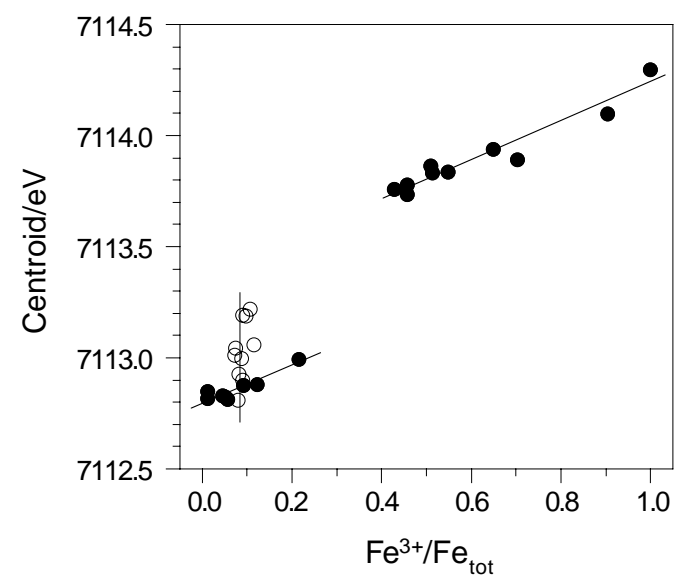

Fig. 3: Correlation between the XANES preedge centroid energy and $\mathrm{Fe}^{3+} / \mathrm{Fe}_{\text {tot }}$ for standards (closed symbols) and natural garnets (open symbols). For $\mathrm{Fe}^{3+} / \mathrm{Fe}_{\text {tot }}<0.3$ the standards belong to the almandine-skiagite series, and for $\mathrm{Fe}^{3+} / \mathrm{Fe}_{\text {tot }}>0.3$ the standards are andradite-skiagite. The solid lines are curves of best fit for the three data sets.

In future work we will further investigate the effect of composition on the pre-edge centroid energy. The electron microprobe flank method has been calibrated using many of the same synthetic garnets as used for these XANES measurements (Höfer and Brey 2007) and compositional or matrix effects are also apparent. In this case, these have been overcome by developing a self-absorption correction.

XANES analyses only require a polished surface (standard thin section or electron probe mount), can be undertaken in air, have a spatial resolution of $\sim 3 \mu \mathrm{m}$, and spectra can be acquired in as little as $10 \mathrm{~min}$. The cubic structure of garnet makes this mineral ideal for the technique since XANES spectra are dependent on orientation for anisotropic materials. If correctly calibrated XANES and the flank method may provide new tools for determining the $f \mathrm{O}_{2}$ of kimberlites.

\section{References}

Berry, A.J, O'Neill, H.St.C., Jayasuriya, K.D., Campbell, S.J., and G.J. Foran., 2003. XANES calibrations for the oxidation state of iron in a silicate glass. American Mineralogist, 88, 967-977.

Delaney, J.S., Dyar, M.D., Sutton, S.R., and Bajt, S., 1998. Redox ratios with relevant resolution: solving an old problem by using the synchrotron microXANES probe. Geology, 26, 139-142.

Gudmundsson, G. and Wood, B.J., 1995. Experimental tests of garnet peridotite oxygen barometry. Contributions to Mineralogy and Petrology, 103, 56-67.

Höfer, H.E. and Brey, G.P., 2007. The iron oxidation state of garnet by electron microprobe: its determination with the flank method combined with major element analysis. American Mineraglogist, 92, 873885.

McCammon, C.A., Griffin, W.L., Shee, S.R., and O'Neill, H.S.C., 2001. Oxidation during metasomatism in ultramafic xenoliths from the Wesselton kimberlite, South Africa: implications for the survival of diamond. Contributions to Mineralogy and Petrology, 141, 287-296.

Westre, T.E., Kennepohl, P., DeWitt, J.G., Hedman, B., Hodgson, K.O., and Solomon, E.I., 1997. A multiplet analysis of Fe K-edge 1s $\rightarrow 3$ d pre-edge features of iron complexes. Journal of the American Chemical Society, 119, 6297-6314.

Woodland, A.B and O'Neill, H.St.C., 1993. Synthesis and stability of $\mathrm{Fe}_{3}{ }^{2+} \mathrm{Fe}_{2}{ }^{3+} \mathrm{Si}_{3} \mathrm{O}_{12}$ garnet and phase relations with $\mathrm{Fe}_{3} \mathrm{Al}_{2} \mathrm{Si}_{3} \mathrm{O}_{12}-\mathrm{Fe}_{3}{ }^{2+} \mathrm{Fe}_{2}{ }^{3+} \mathrm{Si}_{3} \mathrm{O}_{12}$ solutions. American Mineralogist, 78, 1002-1015.

Woodland, A.B and O'Neill, H.St.C., 1995. Phase relations between $\mathrm{Ca}_{3} \mathrm{Fe}_{2}{ }^{3+} \mathrm{Si}_{3} \mathrm{O}_{12}-\mathrm{Fe}_{3}{ }^{2+} \mathrm{Fe}_{2}{ }^{3+} \mathrm{Si}_{3} \mathrm{O}_{12}$ garnet and $\mathrm{CaFeSi}_{2} \mathrm{O}_{6}-\mathrm{Fe}_{2} \mathrm{Si}_{2} \mathrm{O}_{6}$ pyroxene solid solutions. Contributions to Mineralogy and Petrology, 121, 87-98.

Woodland, A.B. and Koch, M., 2003. Variation in oxygen fugacity with depth in the upper mantle beneath the Kaapvaal craton, South Africa, Earth and Planetary Science Letters, 214, 295-310.

Woodland, A.B. and Ross, C.R., 1994. A crystallographic and Mössbauer spectroscopy study of $\mathrm{Fe}_{3} \mathrm{Al}_{2} \mathrm{Si}_{3} \mathrm{O}_{12}-\mathrm{Fe}_{3}{ }^{2+} \mathrm{Fe}_{2}{ }^{3+} \mathrm{Si}_{3} \mathrm{O}_{12}$ (almandine"skiagite") and $\mathrm{Ca}_{3} \mathrm{Fe}_{2}{ }^{3+} \mathrm{Si}_{3} \mathrm{O}_{12}-\mathrm{Fe}_{3}{ }^{2+} \mathrm{Fe}_{2}{ }^{3+} \mathrm{Si}_{3} \mathrm{O}_{12}$ (andradite-"skiagite") garnet solid solutions. Physics and Chemistry of Minerals, 21, 117-132. 